\title{
FOOD SAFETY AND ENVIRONMENTAL AWARENESS OF STREET FOOD VENDORS OF THE DHAKA UNIVERSITY CAMPUS, BANGLADESH
}

\author{
Zeba Farhana*, Nibedita Sutradhar, Tonima Mustafa ${ }^{1}$, M Niamul Naser ${ }^{2}$ \\ Institute of Education and Research, University of Dhaka, Dhaka 1000 \\ Bangladesh
}

\begin{abstract}
Many street vendors earn their livelihoods by selling foods and drinks at the campus of University of Dhaka. Their continuous presence and activities make them one of the key stakeholders of the campus. Both the vendors and customers dispose garbage indiscriminately in the vicinity, which makes the campus dirty, unclean and unhygienic. The aim of this study was to evaluate the environmental awareness and food safety practices among the food vendors with a view to recommend measures to uplift the campus environment. A mixed method was adopted for the study, in which 44 street vendors and 54 consumers were selected purposively from the campus. The results show that the vendors are not aware of food safety issues. The study recommends several measures, such as, designating vending places, registering all street food vendors, improving monitoring system and implementing non-formal environmental education programs for the vendors on food safety and environmental awareness.
\end{abstract}

Key words: Environmental awareness, food vendors, food safety, non-formal education.

\section{INTRODUCTION}

Street foods are widely described as ready-to-eat foods and beverages prepared and sold by vendors or hawkers especially in the streets and other similar places (FAO 1997). Due to the cheapness and easy availability, like many other fastgrowing cities of developing countries, street foods are popular and play an important role in the life of urban dwellers of Dhaka. It is estimated that about 97,000 to 200,000 vendors sell different food items, fruits and beverages in Dhaka (Etzold 2014; CAB 2010). Campus of the University of Dhaka has been the largest gathering place for the street food vendors since flourishing of the street food business in Dhaka (Khatun and Sumiya 2012). The university encompasses 275 acres of land and houses approximately 50,000 people including 44,000 students, 2,000 teachers, 4,400 staffs(University of Dhaka 2018). The presence of such a large number of potential customers at a time attracts the street food vendors to concentrate in this campus. Proximate location of Dhaka Medical College and Suhrawardy Udyan (park) is another reason for such a large gathering (Khatun and Sumiya 2012). These street food vendors are present at almost every open places of the campus (The Daily Star 2010).These vendors prepare food at home and sell in the different locations of the campus or they prepare food at the site of selling. In general, the environment in which these street foods are prepared, handled, catered, preserved and disposed is unsatisfactory and unhygienic (Etzoldet al. 2013). A

*Author for corresponding: < farhanazeba@du.ac.bd>, 1Department of Zoology, Jagannath University, Dhaka, Bangladesh, ${ }^{2}$ Department of Zoology, University of Dhaka, Dhaka, Bangladesh (1)2020 Zoological Society of Bangladesh DOI: https://doi.org/10.3329/bjz.v48i1.47886 
large number of students, staffs, tourists, rickshaw pullers, the campus or they prepare food at the site of selling. In general, the environment in which these street foods are prepared, handled, catered, preserved and disposed is unsatisfactory and unhygienic (Etzoldet al. 2013). A large number of students, staffs, tourists, rickshaw pullers, cart pullers, and other such workers rely on street food vendors for their daily snacks and meals (CAB 2010). Creating awareness among street food vendors and their consumers about using of safe food and water, proper disposal of waste, conserving energy and natural resources, protecting the natural environment, staying informed about environmental issues etc are very essential for the healthy environment (Mustapha 2006). Due to their overwhelming presence almost in every open places of campus, vendors are one of the key stakeholders of the campus environment. As such, examining the food safety practices and environmental awareness of these street food vendors are important for maintaining a healthy environment of the university campus. The major objectives of this study were to evaluate environmental awareness of the street vendors of the campus, to evaluate their food safety practices and to recommend measures to uplift the campus environment.

\section{MATERIAL AND METHODS}

Study area: This research was conducted based on survey of street food vendors and their consumers from 10 purposively selected areas of Dhaka University campus namely Teacher Student Centre (TSC), Mall Chattar, Hakim Chattar, Curzon Hall and adjoining areas of University Laboratory School, Udayan School, Rokeya Hall, Shamsunnahar Hall, Modhur Canteen and Institute of Modern Language.

Study procedure: The methodological approach to this study was designed as mixed method in nature, having both quantitative and qualitative data analysis. 44 street food vendors and 54 consumers, mostly university students, staffs and visitors, were selected from the study area by using purposive sampling method. This study was conducted from November 2017 to April 2018 in the campus of University of Dhaka. The study was based on both primary and secondary data. Standard interview schedule, questionnaire consisting both open and close ended questions were used to obtain primary data from the respondents. Moreover, an observation checklist was followed to collect additional primary data. Secondary data was derived from existing literature like official documents, books, journal papers, reports, conference papers, newspaper articles etc to compare with the findings.

\section{RESULTS AND DISCUSSION}

Demographic analysis of food vendors: Street food vending in the campus is distinctly dominated by male $(95.45 \%)$, which is a common trend among the 
street vendors in Bangladesh (Etzold 2014) and (CAB 2010). Although a very few female vendors were found in the campus, they play an important role by preparing the cooked food and snacks at home that are sold by the men. Considering age, $52 \%$ of the street food vendors were between $21-40$ years, while $22.73 \%$ were below 20 years and $20.45 \%$ were aged between $41-60$ years.

Table 1. Profile of the Street Food Vendors $(n=44)$

\begin{tabular}{lcc}
\hline \multicolumn{1}{c}{ Variables } & Frequency & Percentage \\
\hline Gender & & \\
Male & 42 & 95.45 \\
Female & 02 & 4.55 \\
Age Group (years) & & \\
$<=20$ & 10 & 22.73 \\
$21-40$ & 23 & 52.27 \\
$41-60$ & 09 & 20.45 \\
$>60$ & 02 & 4.55 \\
\hline
\end{tabular}

Educational status of food vendors: Table 2 shows that most of the vendors $(45.45 \%)$ have no formal education, while $40.91 \%$ vendors completed primary education only. Only one vendor completed his graduation and engaged in street food vending as entrepreneurship. As a whole almost $86.36 \%$ vendors have very low education level (no formal education or primary education only), which is much higher than the street food vendors of some other fast-growing Asian cities like Ho Chi Minh City of Vietnam i.e. 60\% (Thanh 2015).

Table 2. Educational Status of the Street Food Vendors $(n=44)$

\begin{tabular}{lcc}
\hline \multicolumn{1}{c}{ Variables } & Frequency & Percentage \\
\hline No Formal Education & 20 & 45.45 \\
Primary & 18 & 40.91 \\
Secondary & 05 & 11.36 \\
Higher Secondary & 00 & 0.00 \\
Graduate & 01 & 2.27 \\
Food Safety Training & & \\
Yes & 0 & 0 \\
No & 44 & 100 \\
\hline
\end{tabular}

Varieties of street foods: Snacks which include Jhalmuri, Velpuri, Fuchkaetc are the most available (36.36\%) food items in the campus. Different types of fruits $\&$ vegetables like banana, jujube (boroi), strawberry, guava, cucumber, coconuts, green-coconuts etc are widely sold in the street. Many cooked foods such as Khichuri, Halua Parata, cakes, chicken fried rice, chicken \&vegetable rolls and some other fast-foods like burger, pizza etc are famous during the lunch time. Besides, few drinks like lemonade, milkshakes, tea, coffee etc and ice-creams are available according to the season. 
Table 3. Types of Street Food

\begin{tabular}{lcc}
\hline Types of Street Food & Frequency & Percentage (\%) \\
\hline Snacks & 16 & 36.36 \\
Cooked Food & 10 & 22.73 \\
Fruits \& Vegetables & 12 & 27.27 \\
Ice-cream & 01 & 2.27 \\
Drinks & 05 & 11.36 \\
\hline
\end{tabular}

Earnings of food vendors: Most of the street food vendors (40.90\%) in the campus of University of Dhaka earn Taka 500 to 1,000 per day, which is calculated deducting all overhead costs (Table-4). This adds up to Taka 15,000 to 30,000 per month or Taka 180,000 to 360,000 per year which is fairly handsome income compared to per capita income of Bangladesh i.e. Taka 127,401 per annum (BBS 2017). Even their income is higher than the daily average wages (Taka 385 per day) of construction labours and factory workers in Dhaka(BBS 2017).

Table 4. Daily income of the Street Food Vendors $(n=44)$

\begin{tabular}{lcc}
\hline $\begin{array}{c}\text { Income/Profit Per Day } \\
\text { (in Taka) }\end{array}$ & Frequency & $\begin{array}{c}\text { Percentage } \\
\text { (\%) }\end{array}$ \\
\hline Upto 500 & 12 & 27.27 \\
$501-1000$ & 18 & 40.90 \\
$1001-2000$ & 08 & 18.18 \\
$2001-4000$ & 02 & 4.55 \\
$>4000$ & 04 & 9.09 \\
\hline
\end{tabular}

Food Safety Practices of Street Food Vendors: Three quarter (75\%) of the food vendors cooked/prepared foods in advance in their vending shops while the rest bought their foods from different shops or brought them from their home in cooked condition (Table-5). Similar findings were observed by CAB (2010) i.e. $68 \%$ in different locations of Dhaka city. However, $82 \%$ of the food was prepared on site. Eighty six percent vendors handle foods with bare hand and $56.82 \%$ vendors wash their hands in clean water each time before handling of food (Table-5). These results show that the vendors are not aware of food safety issues. None of the vendors had any training on food safety. Fifty four percent vendors covered their foods from dust and in $72.73 \%$ cases no flies were found sitting on the foods. But most of the vendors $(86.36 \%)$ do not cover their utensils. Fifty nine percent vendors clean used utensils with bucket water but without soap. All the food vendors use tap water for preparing food, cleaning utensils and as drinking water. As a whole, street food vendors have very little awareness and effort in terms of food safety. 
Table 5. Food Safety Practices of Street Food Vendors (n=44)

\begin{tabular}{|c|c|c|c|c|}
\hline \multirow[t]{3}{*}{ Observation } & \multicolumn{4}{|c|}{ Response } \\
\hline & \multicolumn{2}{|c|}{ Yes } & \multicolumn{2}{|c|}{ No } \\
\hline & Nos. & $\%$ & Nos. & $\%$ \\
\hline The food is prepared: & 11 & 25 & 0 & 0 \\
\hline At home /On site & 33 & 75 & 0 & 0 \\
\hline Vendor handles food with bare hand & 38 & 86.36 & 6 & 13.64 \\
\hline $\begin{array}{l}\text { Vendor washes hands in water each time } \\
\text { before the handling, preparation and serving } \\
\text { of food }\end{array}$ & 19 & 43.18 & 25 & 56.82 \\
\hline Foods are covered from dust & 24 & 54.55 & 20 & 45.45 \\
\hline Flies are sitting on the foods & 12 & 27.27 & 32 & 72.73 \\
\hline Are utensils covered & 6 & 13.64 & 38 & 86.36 \\
\hline $\begin{array}{l}\text { Are utensils cleaned adequately every time } \\
\text { after use }\end{array}$ & 13 & 59.09 & 9 & 40.91 \\
\hline $\begin{array}{l}\text { Utensils are cleaned with: } \\
\text { Clean water with soap }\end{array}$ & 1 & 7.69 & 0 & 0 \\
\hline Clean water with no soap & 12 & 92.31 & 0 & 0 \\
\hline Stall far from open drain & 8 & 18.18 & 36 & 81.82 \\
\hline
\end{tabular}

Environmental Awareness of Street Food Vendors: Most of the vending stalls $(81.82 \%)$ were found near some open drains and $68.18 \%$ stalls had garbage around them. Many of the vending stalls (56.82\%) did not have garbage receptacles. Three fourth of the vendors dispose their garbage in nearby drains $(38.64 \%)$ or near the stall $(36.36 \%)$.

Table 6. Environmental Awareness of Street Food Vendors (n=44)

\begin{tabular}{lcccc}
\hline \multicolumn{1}{c}{ Observation } & \multicolumn{3}{c}{ Response } \\
\cline { 2 - 5 } & \multicolumn{2}{c}{ Yes } & No \\
& Nos. & $\%$ & Nos. & $\%$ \\
Garbage around the vending stall & 30 & 68.18 & 14 & 31.82 \\
Stalls has garbage receptacles & 19 & 43.18 & 25 & 56.82 \\
vendors dispose their garbage in: & 11 & 25 & 0 & 0 \\
Dustbins & 17 & 38.64 & 0 & 0 \\
Nearby drains & 16 & 36.36 & 0 & 0 \\
Near the stall & & & & \\
vendors dispose waste water in: & 12 & 27.27 & 0 & 0 \\
Nearby drains & 8 & 18.18 & 0 & 0 \\
Near the stall & 24 & 54.55 & 0 & 0 \\
Others (no waste water) & & & & 0 \\
\hline
\end{tabular}

Responses from the Consumers: For the study, a total of 54 consumers, all of them were students, were selected randomly from the campus. Among them $23(42.59 \%)$ were males and 31 (57.40\%) were females. Majority of the consumers $(66.66 \%)$ were aged below 20 years while the rest were aged between 21-24 years. Table 7 shows that $42 \%$ consumers think that food vendors rarely 
provide hygienic food (mean 3.87, standard deviation 0.13) and they sometime feel sick or discomfort after eating this street food (mean 2.48, standard deviation 0.14).Even though, forty four percent consumers often buy food from the food vendors (mean 2.41, standard deviation 0.16). This data implies that street food has explicit demand in the university campus despite of the fact that a good number of consumers feel sick from street food. Thirty one percent consumers sometimes dispose the garbage of street food properly and $37 \%$ consumers rarely dispose the garbage of street food properly (mean 3.37, standard deviation 0.15). Interestingly, 59\% consumers think that food vendors lack environmental awareness and personal hygiene (mean 1.51, standard deviation 0.09).

Table 7. Consumers Response on street food hygiene and safety

\begin{tabular}{|c|c|c|c|c|c|c|c|}
\hline \multirow{2}{*}{ Factors } & \multicolumn{7}{|c|}{ Percent (\%) } \\
\hline & 1 & 2 & 3 & 4 & 5 & Mean & SD \\
\hline $\begin{array}{l}\text { Do you think that food vendors } \\
\text { provide hygienic food? }\end{array}$ & 3.7 & - & 27.78 & 42.59 & 25.93 & 3.87 & 0.13 \\
\hline $\begin{array}{l}\text { Do you feel any sickness or } \\
\text { discomfort after eating this food? }\end{array}$ & 2.37 & 25.93 & 42.59 & 7.41 & 3.7 & 2.48 & 0.14 \\
\hline $\begin{array}{l}\text { Do you buy food from the food } \\
\text { vendors of University campus? }\end{array}$ & 20.37 & 44.44 & 18.52 & 7.41 & 9.26 & 2.41 & 0.16 \\
\hline $\begin{array}{l}\text { Do you dispose the garbage of } \\
\text { street food properly? }\end{array}$ & 7.41 & 11.11 & 31.48 & 37.04 & 12.96 & 3.37 & 0.15 \\
\hline $\begin{array}{l}\text { Do you think food vendors lack } \\
\text { environmental awareness \& } \\
\text { personal hygiene? }\end{array}$ & 59.26 & 31.48 & 9.26 & - & - & 1.50 & 0.09 \\
\hline $1=\mathrm{A}$ &, 2 & en, 3 & pmeti &, $4=1$ & and & Jever & \\
\hline
\end{tabular}

Street food vendors have become part of the university campus mainly due to their overwhelming demands to the students for cheap price. It is a good source of earning for the vendors. Absence of monitoring by the university administration allows them to open their business in any open places of the campus. Most of the vendors did not undergo any formal education or completed primary education only. They are neither trained on food safety nor aware of food safety issues. But street food vending is a delicate business which requires trainings about hygiene and safe food handling practices (Etzold 2014). As a result good number of students are getting sick from street food. Moreover, vending stalls were found near open drains and did not have garbage receptacles. These vendors dispose their garbage in nearby drains or near the stall. The consumers also do not dispose the garbage of street food properly. It is not possible to clean up the garbage widely spread over 275 acres campus by merely 60 cleaner staffs of the university administration (University of Dhaka 2018). As a result, university campus remains always dirty due to 
indiscriminate garbage disposition. Since the street food vendors have no formal education, they are not in a position to ponder over neither food safety nor environmental issues. Again, they are the part of the campus life and environment. Therefore, they need to be educated properly to ensure healthy foods to the students. As the vendors are diverse and scattered everywhere, their education for the food safety and environment should be locality specified. They should be taught to be eco-friendly, and co-existent with their environment (Chaturvedi and Kumari 2014) and why they themselves should take responsibility for the cleanliness of their vending site by disposing their waste in an adequate way and by sweeping their site (Etzold 2014). An earlier survey found that bacterial count of sampled street food reduced sharply after a group of food vendors were given training on food safety (CAB 2010). Most of the vendors are aged below 40 years and almost $40 \%$ of them have undergone primary education. As such, non-formal education can play a very important role to improve the food safety practices of the vendors and as well as to inculcate environmental awareness.

\section{CONCLUSIONS}

Street food vendors have become an inseparable part of university campus due to their essential demands among the students. Their presence is likely to increase day by day. If present trend continues then the food safety and the environmental issues are also likely to degrade further. To uplift the campus environment as well as food safety and hygiene, the authorities should consider few measures such as designate vending places and register all street food vendors, arrange non-formal education programs for the street food vendors on food safety and environmental awareness, improve monitoring system of the street food vendors by the university administration and other student organizations.

\section{LITERATURE CITED}

AMOATEMAA, A. S.2017. Implications of Hawking Activities on the Kumasi Campus of University of Education, Winneba. British Journal of Education, Society \& Behavioural Science, 20(4), 1-10.

BBS. 2017. Statistical Pocket Book of Bangladesh. Dhaka: Bangladesh Bureau of Statistics, Ministry of Planning, Goverment of Bangladesh.

CAB. 2010. Institutionalization of Healthy Street Food System in Bangladesh. A Pilot Study with three Wards of Dhaka City Corporation as a Model. Dhaka: Consumers Association of Bangladesh.

CHATURVEDI, A., AND KUMARI, R. A. 2014. Environmental Awareness Through Education. IV(2), 93.

ETZOLD, B. 2014. Towards Fair Street Food Governance in Dhaka - Moving from Exploitation and Eviction to Social Recognition and Support. In C. M. de Cassia Vieira Cardoso, Street Food. Culture, Economy, Health and Governance (pp. 61-82). Newyork: Routledge.

ETZOLD, B., HOSSAIN, M. A., AND RAHMAN, S. 2013. Street Food Vending in Dhaka: Livelihoods of the Urban Poor and the Encroachment of Public Space. Dhaka: Bangladesh Institute of Planners. 
FAO. 1997. Report of an FAO technical meeting on street foods. Rome: FAO.

HUSSEIN, O. M. 2014. Street Hawking and its Impacts on Nairobi Central Business District Urban Space. Nairobi: Kenyatta University.

KHATUN, H., AND SUMIYA, N. N. 2012. Spatial Pattern of Street Food in Dhaka City. Oriental Geographer, 56 (1\&2), 97-112.

MUSTAPHA, A. 2006. The impact of Home and school environmental .Towards the empowerment of adolescents for national reconstruction. Zaria Journal of Education, 2(1):150-152.

OGHENEKOHWO, J. E. 2015. Pattern of Food Hygiene and Environmental Health Practices among Food Vendors in Niger Delta University. European J Food Science \& Tech. 3 (1): 24-40.

THANH, T. N. 2015. Food safety behavior, attitudes and practices of street food vendors and consumers in Vietnam. Ghent: Ghent University.

THE DAILY STAR. 2010, December 05. The Daily Star. Retrieved August 12, 2018, from https://www.thedailystar.net/news-detail-164748

UNIVERSITY OF DHAKA. 2018. du_at_a_glance. Retrieved August 06, 2018, from University of Dhaka: http://www.du.ac.bd/main_menu/the_university/du_at_a_glance

(Manuscript received on 10 March, 2020 revised on 11 June, 2020) 